\title{
Hypertension in Neonates: Need for Future Research
}

\section{Deepak Sharma*}

National Institute of Medical Sciences, Jaipur, Rajasthan, India

\begin{abstract}
Hypertension in neonatal is labelled when as blood pressure (BP) is above 2 standard deviation or $>95^{\text {th }}$ percentile over the mean of systolic and/or diastolic BP in similar neonate with respect to post-menstrual age, post-natal age and weight. It is an infrequently seen and rarely reported entity in NICU. Presently there are no normogram in neonatal population for BP when compared to pediatric and adult population. It is usually diagnosed during routine BP monitoring but needs timely identification and treatment, with Malignant HT needing urgent treatment, otherwise delay in management can lead to end organ dysfunction and poor long term neonatal outcomes. There are no evidence based guidelines for treatment $\mathrm{HT}$ and present treatment guidelines are consensus based. This review article tries to covers all aspects of neonatal hypertension.
\end{abstract}

Keywords: Neonatal hypertension; Diagnosis; Management; Antihypertensive

\begin{abstract}
Abbreviations: ACE: Angiotensin-Converting Enzyme; BP: Blood Pressure; CT: Computerized Tomography; DBP: Diastolic Blood Pressure; HT: Hypertension; IBP: Intra-Arterial Blood Monitoring; MRA: Magnetic Resonance Angiography; NICU: Neonatal Intensive Care Unit; PDA: Patent Ductus Arteriosus; PRA: Plasma Renin Activity; SBP: Systolic Blood Pressure; VCUG: Voiding Cystoureterogram
\end{abstract}

\section{Introduction}

Neonatal hypertension (NHT) was diagnosed 4 decades ago, but still not much importance have been given when compared to other areas of neonatology, hence presently still there is inadequate insight for NHT [1]. When compared to paediatric and adult population where there are cut-off values of blood pressure for labelling hypertension, there are no such cut-off value in the neonatal age group. There are also no management protocol defining first line and second line anti-hypertensive to be used in these hypertensive neonates, when compared to paediatric and adult population [2]. In this review article we will cover in brief about various aspects of neonatal HT and details over this issue can be read from other published reviews of the author $[1,3,4]$. There is urgent need for research over this issue so that neonatal hypertension can be managed in protocolised manner as the paediatric and adult hypertension.

\section{How common is neonatal hypertension?}

The occurrence of NHT in different studies is $1 \%-2.5 \%$ in NICU admitted neonates $[5,6]$. In pediatric population the prevalence of hypertension is around 3\% and is often indicative of an underlying disease process [7]. The health care personal who are handling neonatal population should be familiar with neonatal BP normogram with respect to post-menstrual age, post-natal age, birth weight and gender, various methods and correct way for BP measurement in neonates, finding causative factor for NHT and management of NHT [3,8].

\section{What is the definition of neonatal HT in neonates?}

Hypertension in neonatal period or NHT as per definition is when the $\mathrm{BP}$ is above 2 standard deviation or more than $95^{\text {th }}$ percentile over the mean of systolic and/or diastolic BP for infants of similar size, gestational age and postnatal age [9]. In adult population BP $\geq 140 / 90$ $\mathrm{mmHg}$ regardless of body size, sex and age [10] and in paediatric population average systolic BP (SBP) and/or diastolic BP (DBP) more than $\geq 95^{\text {th }}$ percentile for age, sex and height on $\geq 3$ occasion is considered HT [7].

\section{What is the normal BP in neonatal population?}

Neonatal BP is a continuously changing variable and it is affected by multiple factors. In neonatal age group, important factors affecting neonatal BP are corrected gestational age, gestational age at time of birth, postnatal age and weight as per the gestational age $[8,11]$. The other factors which have been implicated for effecting neonatal BP are maternal drug intake, Apgar scores, hypertension in mother during pregnancy, delivery method, type of anaesthesia given to mother during new-born birth $[12,13]$, neonatal drugs and neonatal morbidities. When neonatal BP is high and before stating it as NHT, all the BP effecting factors should be taken care of right interpretation of neonatal BP [14].

The initial work for finding normogram of neonatal BP was done by Zubrow et al. [15] and he published Zubrow's charts Figures 1-3. Recently from India, Samanta et al. [16] have published percentile charts of BP in new-born. Neonatal BP charts after 2 weeks of postnatal age have been published by Dionne et al. [5].

\section{How is blood pressure measured in neonates?}

The various methods of BP monitoring in neonates includes both non-invasive and invasive method. The gold standard for neonatal BP measurement is Intra-arterial blood monitoring (IBP) and commonly used arteries are umbilical, radial, and posterior tibial [17]. There are two methods for non-invasive BP monitoring are using oscillometric device and Ultrasonic Doppler. The details of method, standard protocol of neonatal BP measurement and various precautions need to be taken while during non-invasive and invasive BP measurement are summarized in Figure 4 and can be read in detail from other published reviews $[1,3,4]$.

\section{What are the common causes of neonatal HT?}

The causes of NHT are multiple and include both congenital and

*Corresponding author: Dr. Deepak Sharma, Consultant Neonatologist, National Institute of Medical Sciences, Jaipur, Rajasthan, India, Tel: +919462270002; E-mail: dr.deepak.rohtak@gmail.com

Received August 20, 2017; Accepted September 11, 2017; Published September 19, 2017

Citation: Sharma D (2017) Hypertension in Neonates: Need for Future Research. J Neonatal Biol 6: 261. doi:10.4172/2167-0897.1000261

Copyright: (c) 2017 Sharma D. This is an open-access article distributed under the terms of the Creative Commons Attribution License, which permits unrestricted use, distribution, and reproduction in any medium, provided the original author and source are credited. 

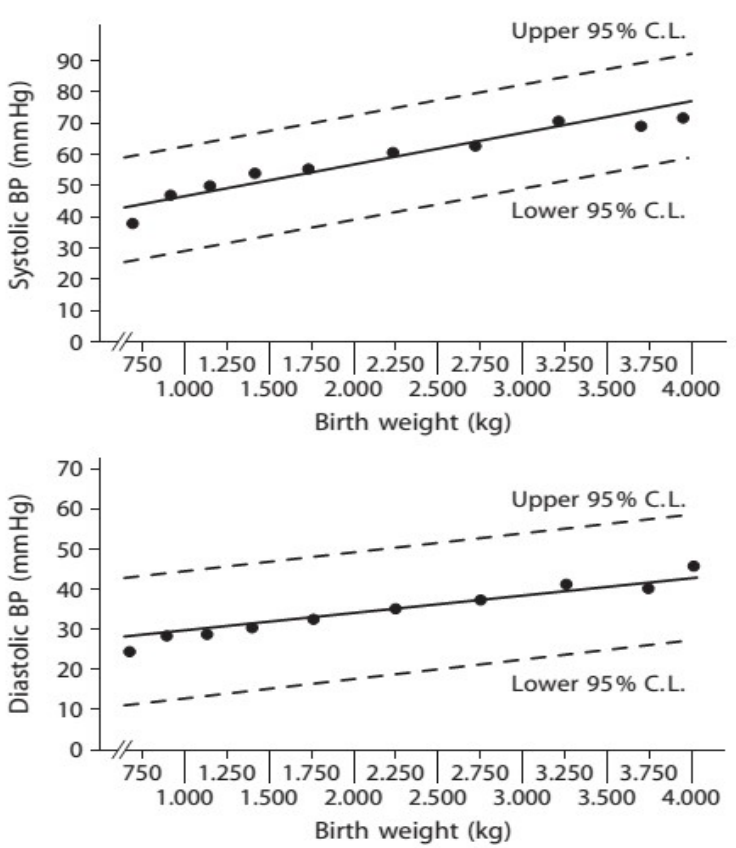

Figure 1: Linear regression of mean systolic and diastolic blood pressures by birth weight on day 1 of life, with $95 \%$ confidence limits (upper and lower dashed lines).

Adopted from [15]
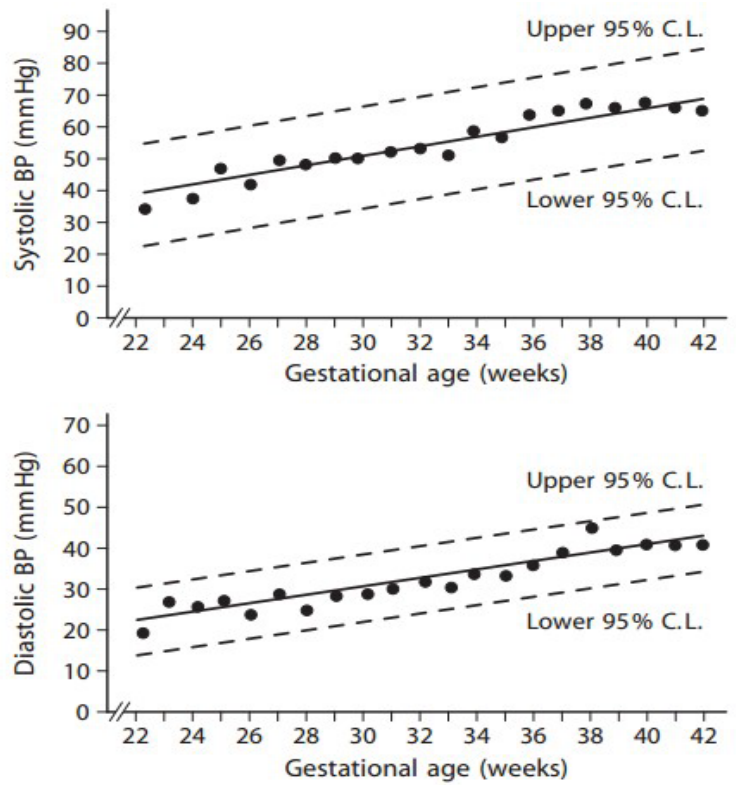

Figure 2: Linear regression of mean systolic and diastolic blood pressures by gestational age on day 1 of life, with $95 \%$ confidence limits (upper and lower dashed lines).

Adopted from [15]

iatrogenic causes. NHT causes have been tabulated system wise in Table 1 and Figure 5. Top three common cause of NHT are thrombi in umbilical artery, chronic lung disease and coarctation of aorta [17]. In pediatric population the most common causes of HT are renal in origin and include renal parenchymal disease, renovascular disease and coarctation of the aorta [7].
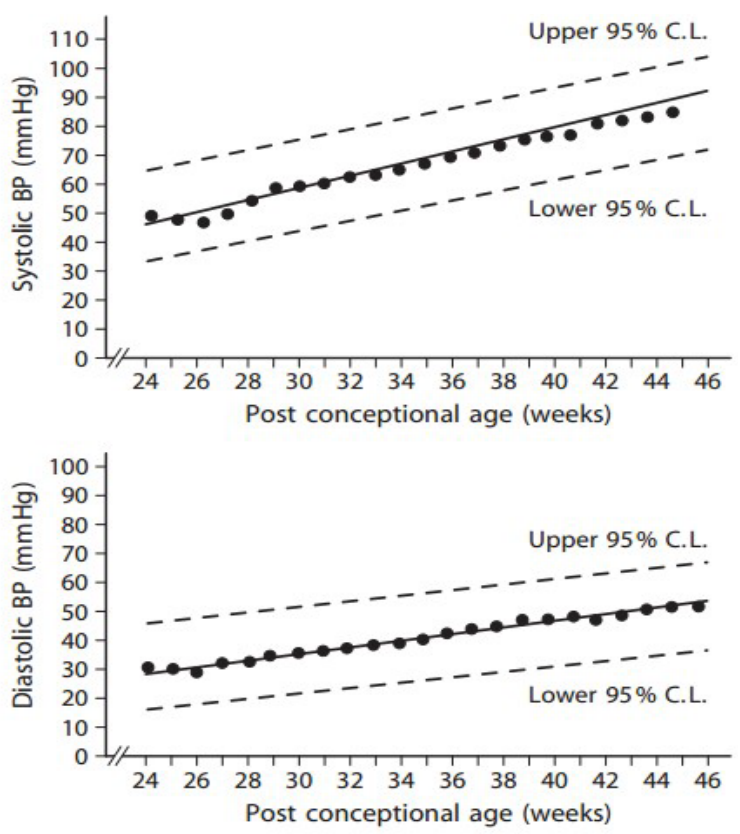

Figure 3 Linear regression of mean systolic and diastolic blood pressures by post-conceptual age in weeks, with $95 \%$ confidence limits (upper and lower dashed lines).

Adopted from [15]

\section{What are the clinical features of neonatal HT?}

The clinical features of NHT have various spectrum, from being asymptomatic on one end to life threatening complications on the other end. NHT is noticed when BP is measured in admitted neonate as part of vitals BP (Table 2). NHT have vague clinical features similar to features seen in other neonatal morbidities, thus making suspicion of NHT difficult on clinical features basis [3]. The life threating complications of neonatal HT includes congestive cardiac failure, cerebral hemorrhage, cardiogenic shock [18], neonatal seizures [19] and hypertensive retinopathy [20]. The infants in follow up have excessive irritability and failure to thrive as clinical feature of neonatal HT [21].

\section{How to approach the case of neonatal HT?}

Neonatal HT in majority of the cases has any underlying pathology and hence each neonate with HT should have detail evaluation for identifying the cause. The approach includes history taking (prenatal, perinatal and postnatal), clinical examination and laboratory investigations.

- History: The neonatal HT evaluation starts from detailed history taking.

o Prenatal history: Ante-natal drug intake by mother (drugs of abuse, maternal diabetes), targeted imaging for fetal anomalies scan for antenatally diagnosed malformations.

o Perinatal history: History of delayed cry or passage of meconium.

o Postnatal history: History taking should include the history of placement of umbilical catheter (both artery and venous), neonatal medicine, neurological status of infant during BP measurement, neonatal post-natal course and morbidities in the nursery, appropriateness of BP measurement method, 


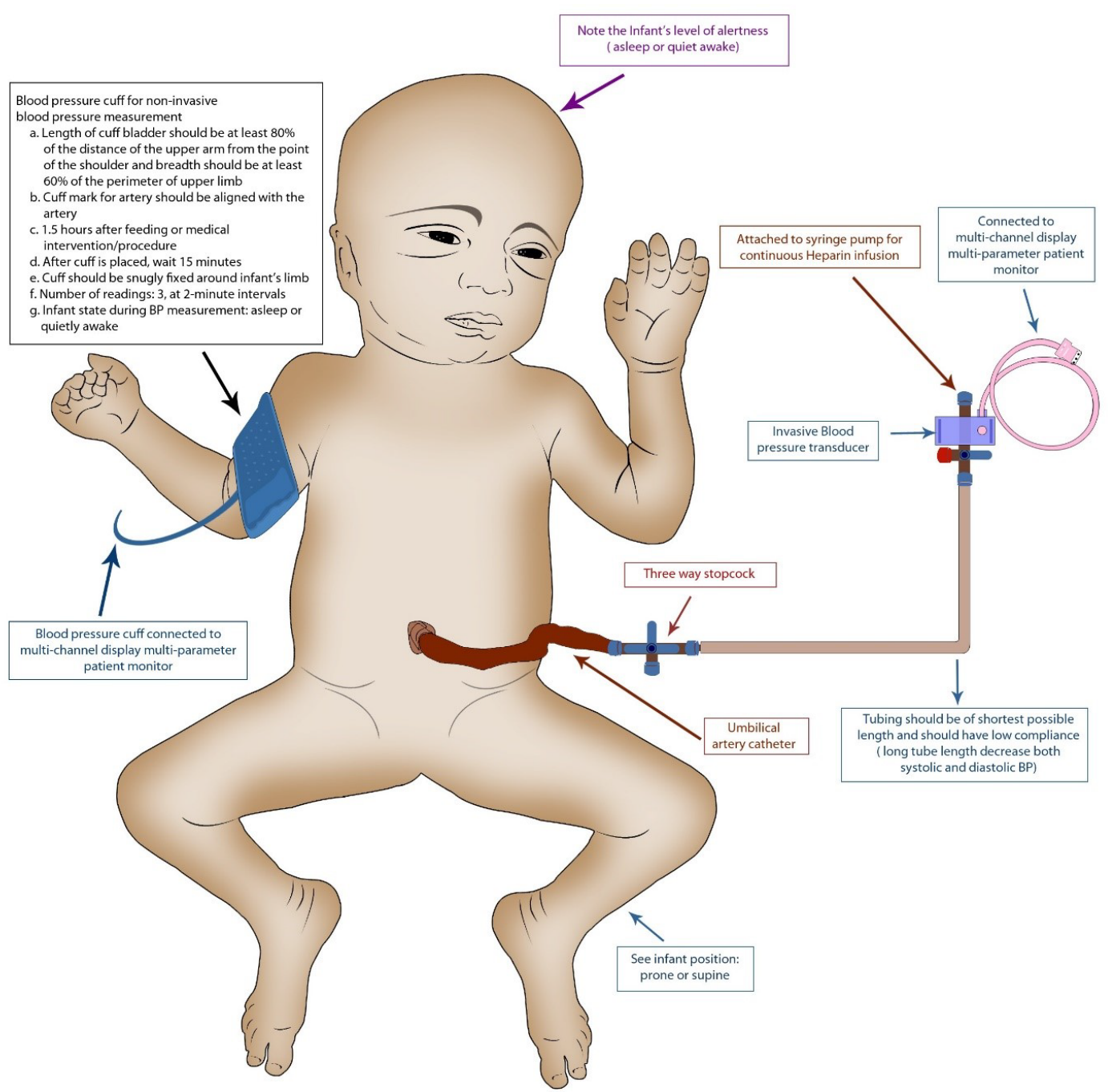

Figure 4: Figure showing invasive and non-invasive method of BP measurement in neonate. Precautions to be taken during BP measurement have also been highlighted.

trends of BP value readings and associated complications of NHT [3].

- Examination: Neonate should be examined with detail physical evaluation to find out any obvious finding. Blood pressure should be measured in both upper and lower limbs. Examine the infant for clinical features of HT and serious complications as treatment will depend upon the severity of presentation. The neonate should be examined for any syndromic facies leading to NHT. The cardiovascular system examination should include presence of abnormal heart sounds, pulses of upper limbs and lower limbs, heart rate and presence of heart failure. Abdominal and genitourinary system examination should be done for any abdominal mass or genital anomalies $[5,9,17]$.

- Laboratory evaluation: The first line and second line investigations that are to be done in case of NHT are tabulated in Table 3. If the initial investigation direct towards renal pathology as cause of neonatal HT, than it needs detailed evaluation with various investigation including [voiding cystoureterogram (VCUG) for urinary tract malformation (only in case of hydronephrosis more than grade II, and later in the course, if hydronephrosis persists (6-8 weeks later), radionuclide scintigraphy for perfusion abnormality detection (DTPA, MAG3) and DMSA scan for suspicious arterial infarction and for assessment of renal function and not stenosis of renal artery (to be done only with corrected age of 3 months, only in the later course). If there is suspicion of renal artery stenosis or thromboembolism, the first line investigation will be plasma renin activity, secondary, if lab values are abnormal than plan for MR-angiography. Magnetic resonance angiography (MRA) is the gold standard for diagnosis of renovascular HT [22]. Plasma renin activity (PRA) is increased in renovascular disease and is low in primary hyperaldosteronism. If clinical examination directs towards endocrinal cause for neonatal HT than thyroid function tests (clinical features of hyperthyroidism like prematurity, growth retardation, tachycardia, irritability, poor weight gain, goiter, prominent eyes, frontal bossing, hypertension and craniosynostosis), serum cortisol, serum aldosterone, urinary 17-hydroxysteroids and 17-ketosteroids for Cushing syndrome and congenital adrenal hyperplasia, 


\begin{tabular}{|c|c|}
\hline Reno-vascular causes & Neurological \\
\hline $\begin{array}{ll}\text { - } & \text { Renal artery thrombosis } \\
\text { - } & \text { Thromboembolism } \\
\text { - } & \text { Renal artery stenosis } \\
\text { - } & \text { Renal venous thrombosis } \\
\text { - } & \text { Compression of renal artery } \\
\text { - } & \text { Idiopathic arterial calcification }\end{array}$ & $\begin{array}{ll}\text { - } & \text { Cushing's disease } \\
\text { - } & \text { Neural crest tumor } \\
\text { - } & \text { Pain } \\
\text { - } & \text { Intraventricular hemorrhage } \\
\text { - } & \text { Subdural hematoma } \\
\text { - } & \text { Familial dysautonomia } \\
\end{array}$ \\
\hline Renal parenchymal disease & Pulmonary \\
\hline $\begin{array}{ll}\text { - } & \text { Obstructive uropathy } \\
\text { - } & \text { Congenital malformations } \\
\text { - } & \text { Polycystic kidney disease } \\
\text { - } & \text { Tuberous sclerosis } \\
\text { - } & \text { Ureteropelvic junction obstruction } \\
\text { - } & \text { Unilateral renal hypoplasia } \\
\text { - } & \text { Congenital nephrotic syndrome } \\
\text { - } & \text { Gyemerulonephritis } \\
\text { - } & \text { Renal tumors like Mesoblastic nephroma } \\
\text { - } & \text { Wilms tumour } \\
\end{array}$ & $\begin{array}{l}\text { - } \quad \text { Bronchopulmonary dysplasia/chronic lung disease } \\
\text { - } \quad \text { Pneumothorax } \\
\end{array}$ \\
\hline Acquired renal conditions & Cardio vascular system \\
\hline $\begin{array}{ll}\text { - } & \text { Acute tubular necrosis } \\
\text { - } & \text { Cortical necrosis } \\
\text { - } & \text { Interstitial nephritis } \\
\text { - } & \text { Hemolytic-uremic syndrome } \\
& \text { Obstruction (stones) }\end{array}$ & $\begin{array}{ll}\text { - } & \text { Coarctation of aorta } \\
\text { - } & \text { Post PDA ligation } \\
& \text { Ductal aneurysm }\end{array}$ \\
\hline Endocrine & Medications \\
\hline $\begin{array}{ll}\text { - } & \text { Congenital adrenal hyperplasia } \\
\text { - } & \text { Primary Hyperaldosteronism } \\
\text { - } & \text { Hyperthyroidism } \\
& \text { Pseudohypoaldosteronism type II }\end{array}$ & $\begin{array}{ll}\text { A. } & \text { Neonatal drugs } \\
\text { - } & \text { Steroids like Dexamethasone } \\
\text { - } & \text { Toxicity of Vitamin D } \\
\text { - } & \text { Methyl xanthine/Theophylline } \\
\text { - } & \text { Caffeine } \\
\text { - Pancuronium } & \text { Phenylephrine } \\
\text { B. Maternal drugs } \\
\text { - Cocaine } \\
\text { - Heroin }\end{array}$ \\
\hline Miscellaneous & Essential HTN/Idiopathic hypertension \\
\hline $\begin{array}{ll}\text { - } & \text { Total parenteral nutrition } \\
\text { - } & \text { Closure of abdominal wall defect like omphalocele/gastrochisis } \\
\text { - } & \text { Adrenal hemorrhage } \\
\text { - } & \text { Adrenal tumors } \\
\text { - } & \text { Fluid overload } \\
\text { - } & \text { Traction } \\
\text { - } & \text { Extracorporeal membrane oxygenation }(\mathrm{ECMO}) \\
\text { - } & \text { Birth asphyxia }\end{array}$ & \\
\hline
\end{tabular}

Adopted from [3]

Table 1: Table showing various causes of Neonatal hypertension (system wise).

urinary metanephrines and vanillyl mandelic acid for pheochromocytoma and congenital neuroblastoma, urine for toxicology screen if suspicion is of mother drug addiction need to be done. Computerized tomography (CT) in children should be avoided and abdominal MR is superior to detect abdominal masses, if available and I131metaiodobenzyl guanidine scanning for pheochromocytoma. In rare case renal biopsy need to be done to see for any intrinsic renal pathology $[3,5,22,23]$.

\section{What are the treatment options of neonatal hypertension?}

The treatment of NHT is started if the neonatal BP is $\geq 99^{\text {th }}$ percentile for the postnatal age, gender, weight and gestational age. Iatrogenic causes like inotropes, pain, and umbilical catheter should be sought and appropriately treated before starting any medication for NHT. If endocrinal disorders are the causative agent for NHT than it needs treatment with appropriate hormones [23]. The anti-hypertensive drugs used in treatment of NHT with dosages have been tabulated in Table 4. The first line of management of neonatal HT is usually an angiotensin-converting enzyme (ACE) inhibitor and prior to its usage renal artery stenosis should be ruled out. Captopril (ACE inhibitor) has been shown to be effective in treatment of neonatal HT, but it is prone to cause an exaggerated fall in BP in premature infants [24]. In full-term and older infants, Task Force recommendations should be followed for management of neonatal HT [25]. The antihypertensive can be divided on the basis of onset of action as fast onset (within minutes to hours) and slow onset (takes few days for onset). The drugs with fast onset are used in treatment of malignant crisis where the goal is get the normal $\mathrm{BP}$ as soon as possible. This group includes vasodilators (arteriolar and venous), calcium channel blockers and $\alpha$ - and $\beta$-adrenergic antagonists. The slow onset action drugs include diuretics including loop diuretics and thiazides, aldosterone antagonist, Central- $\alpha$ agonist and ACE inhibitors. NHT can be divided as malignant (blood pressure more than or equal to $99^{\text {th }}$ percentile), moderate (blood pressure between 


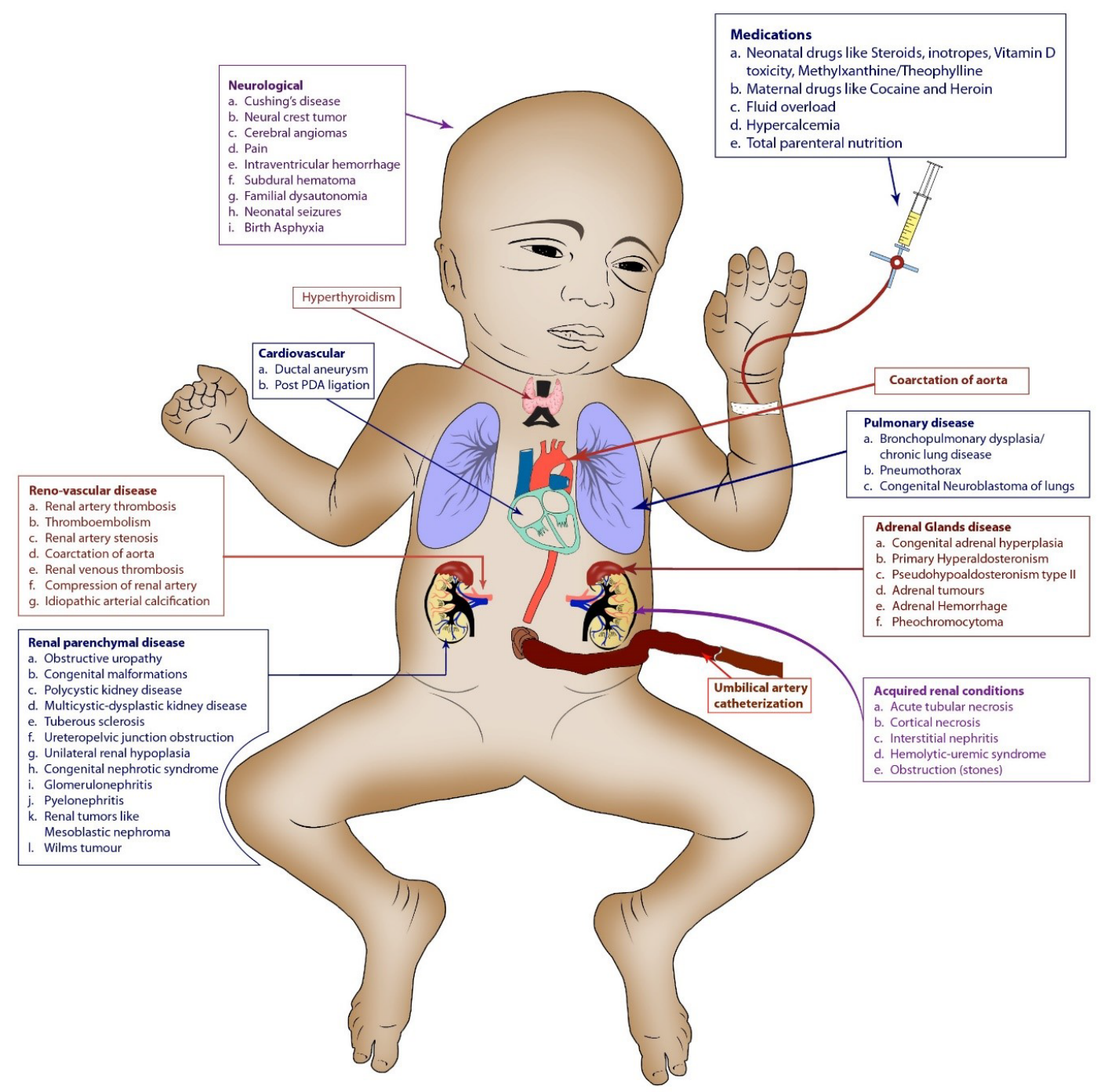

Figure 5 Figure showing various etiologies of neonatal HT system wise.

\begin{tabular}{|l|l|}
\hline S. No. & Clinical features \\
\hline 1 & Apnea \\
\hline 2 & Tachypnea \\
\hline 3 & Hypertonia \\
\hline 4 & Tachycardia \\
\hline 5 & Cyanosis \\
\hline 6 & Mottling \\
\hline 7 & Lethargy/decreased acceptance \\
\hline 8 & Vomiting \\
\hline 9 & Excessive irritability \\
\hline 10 & Neonatal seizures \\
\hline 11 & Recurrent feed intolerance \\
\hline 12 & Abdominal distension \\
\hline 13 & Hematuria \\
\hline 14 & Failure to thrive \\
\hline 15 & Congestive cardiac failure \\
\hline 16 & Cerebral hemorrhage \\
\hline 17 & Cardiogenic shock \\
\hline 18 & Hypertensive retinopathy \\
\hline
\end{tabular}

Table 2: Various clinical features of neonatal hypertension. 


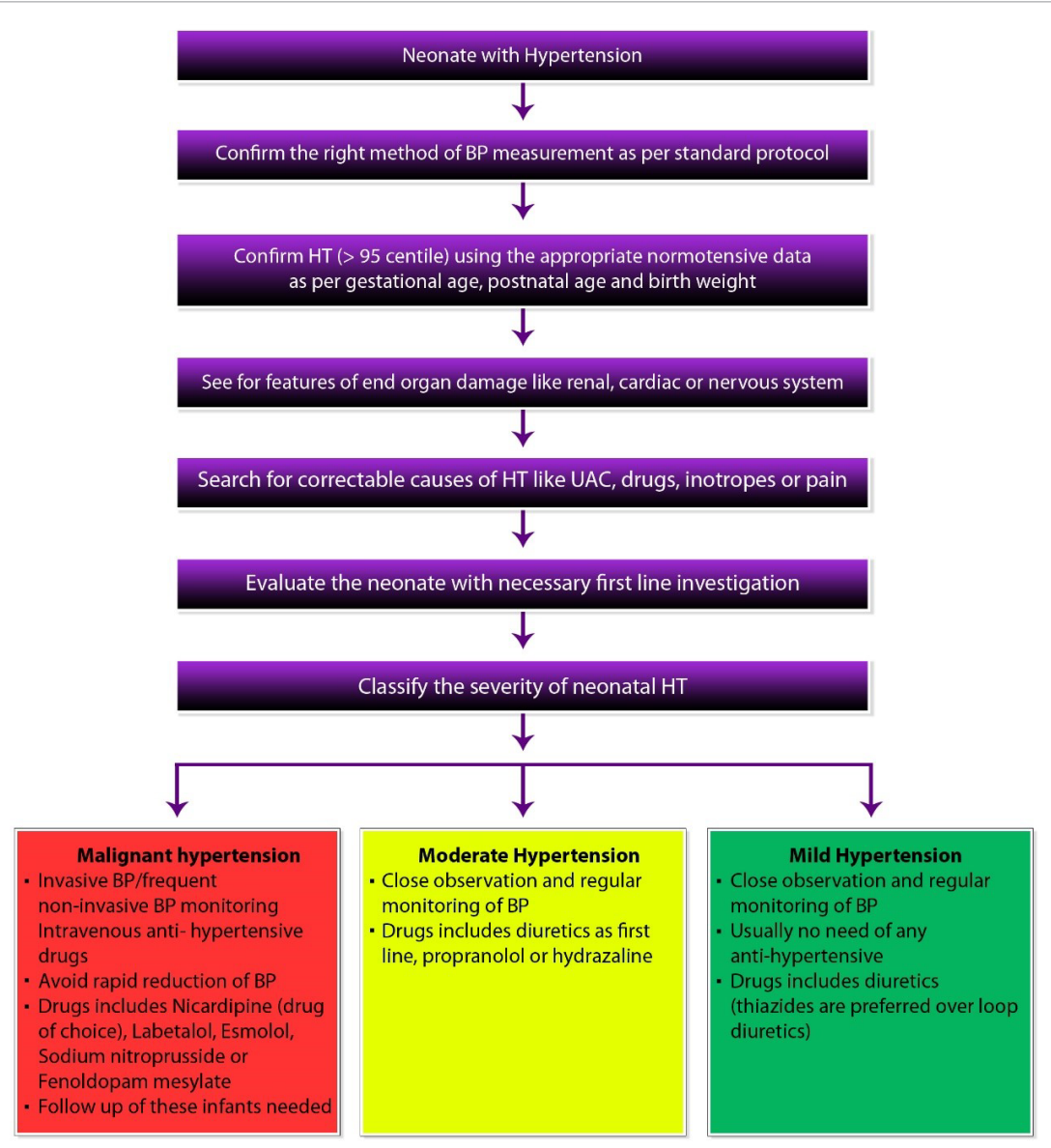

Figure 6: Figure showing management protocol for neonatal hypertension.

\section{First line investigations}

- Complete blood count and platelet count (Thrombocytopenia in renal vein thrombosis)

- Urine complete analysis and culture (Hematuria/renal cast/infection)

- Urine protein: urine creatinine ratio

- Urine albumin: urine creatinine ratio

- $\quad$ Serum electrolytes (Hypokalemia/hyperkalemia)

- $\quad$ Serum calcium (Hypercalcemia)

- Serum creatinine

- Blood urea nitrogen

- Arterial blood gas analysis

- Coagulation profile (Renal artery/vein thrombosis)

- D-dimer assay (Renal artery/vein thrombosis)

- $\quad$ Chest x-ray (Cardiomegaly)

- Renal Doppler and ultrasound (Renal artery/vein-thrombosis/obstruction/stenosis)

- Echocardiogram (Structural/functional anomalies)

- $\quad$ Cardiac enzymes (Cardiac injury)

- Head ultrasound (Intraventricular/ cerebral hemorrhage)

\section{Second line investigations}

- $\quad$ Thyroid Hormone (Hyperthyroidism)

- Urine VMA/HVA (Vanillylmandelic acid/homovanillic acid) (pheochromocytoma and neuroblastoma)

- $\quad$ Plasma renin activity (Renal artery stenosis/thrombosis)

- $\quad$ Aldosterone (Cushing syndrome/congenital adrenal hyperplasia)

- $\quad$ Serum cortisol (Cushing syndrome/congenital adrenal hyperplasia)

- $\quad$ Urinary 17-hydroxysteroid, 17-ketosteroid (Cushing syndrome/congenital adrenal hyperplasia)

- Abdominal/pelvic ultrasound (Mass or malformations)

- Urine for toxicology screening (Suspicion of mother drug addict)

- $\quad$ Voiding cystoureterogram (VCUG) (Hydronephrosis)

- $\quad$ Aortography

- Renal angiography (Renal artery stenosis/thrombosis)

- Nuclear scan DTPA (Diethylene triamine pentaacetic acid)/Mag-3/DMSA (Renal infarct/assessment of renal function)

- $\quad$ MRI abdomen (Abdominal mass)

- $\quad \mathrm{I}^{131}$ metaiodobenzyl guanidine (Pheochromocytoma)

Adopted from [3]

Table 3: Various laboratory investigation to be done in case of neonatal hypertension. 


\begin{tabular}{|c|c|}
\hline Drug Class & Name of drug and Recommended dose \\
\hline \multicolumn{2}{|l|}{ Fast onset of action } \\
\hline Calcium-channel blockers & $\begin{array}{l}\text { Nicardipine (IV) } 0.5-4 \mathrm{mg} / \mathrm{kg} / \mathrm{min} \text { Infusion (central line) } \\
\text { Amlodipine (PO) Initial: } 0.1 \mathrm{mg} / \mathrm{kg} / \mathrm{dose} \text { Max: } 0.6 \mathrm{mg} / \mathrm{kg} / \mathrm{d} \text { Daily to BID } \\
\text { Isradipine (PO) Initial: } 0.05-0.15 \mathrm{mg} / \mathrm{kg} / \mathrm{dose} \text { Max: } 0.8 \mathrm{mg} / \mathrm{kg} / \mathrm{d} \text { TID to QID } \\
\text { Nifedipine (PO) Initial: } 0.25 \mathrm{mg} / \mathrm{kg} / \mathrm{dose} \text { Max: } 2.5 \mathrm{mg} \text { Every } 4-6 \mathrm{~h}\end{array}$ \\
\hline Direct-acting vasodilators & $\begin{array}{l}\text { Sodium nitroprusside (IV) Initial: } 0.25 \mathrm{mg} / \mathrm{kg} / \mathrm{min} \text { Max: } 8 \mathrm{mg} / \mathrm{kg} / \mathrm{min} \text { as continuous infusion } \\
\text { Hydralazine (IV) } 0.2-1.0 \mathrm{mg} / \mathrm{kg} / \mathrm{dose} \text { IV bolus every } 4 \mathrm{~h} \\
\text { Hydralazine (PO) } 0.25-1 \mathrm{mg} / \mathrm{kg} / \mathrm{dose} \text { TID-QID. Not to exceed } 7.5 \mathrm{mg} / \mathrm{kg} / \mathrm{day} \\
\text { Minoxidil (PO) } 0.1-0.2 \mathrm{mg} / \mathrm{kg} / \mathrm{dose} \text { BID-TID }\end{array}$ \\
\hline$\alpha$-and $\beta$ adrenergic antagonists & $\begin{array}{l}\text { Labetalol (PO) } 1 \mathrm{mg} / \mathrm{kg} / \mathrm{dose} \text { BID-TID, up to } 10 \mathrm{mg} / \mathrm{kg} / \mathrm{day} \\
\text { Labetalol (IV) } 0.2-1 \mathrm{mg} / \mathrm{kg} / \mathrm{dose} \text { IV bolus every } 4-6 \mathrm{~h} \text { or } 0.25-3 \mathrm{mg} / \mathrm{kg} / \mathrm{h} \text { constant infusion } \\
\text { Carvedilol (PO) } 0.05-0.4 \mathrm{mg} / \mathrm{kg} / \text { dose BID to TID }\end{array}$ \\
\hline$\beta$-Antagonists & $\begin{array}{l}\text { Esmolol (IV) } 125-1000 \mathrm{mg} / \mathrm{kg} / \mathrm{min} \text { Infusion } \\
\text { Propranolol (IV) } 0.01-0.15 \mathrm{mg} / \mathrm{kg} / \mathrm{dose} \\
\text { Propranolol (PO) } 0.5-6 \mathrm{mg} / \mathrm{kg} / \mathrm{d}\end{array}$ \\
\hline a-Antagonist & Prazosin (PO) Initial: $5 \mathrm{mg} / \mathrm{kg} / \mathrm{dose} 25-400 \mathrm{mg} / \mathrm{kg} / \mathrm{d}$ TID to QID \\
\hline \multicolumn{2}{|l|}{ Slow onset of action } \\
\hline ACE inhibitors & $\begin{array}{l}\text { Captopril (PO) Neonates: Initial: } 0.01 \mathrm{mg} / \mathrm{kg} / \mathrm{dose} \text { Max: } 1.5 \mathrm{mg} / \mathrm{kg} / \mathrm{d} \text { TID to QID } \\
\text { Infants: Initial: } 0.1-0.3 \mathrm{mg} / \mathrm{kg} / \mathrm{dose} \text { Max: } 6 \mathrm{mg} / \mathrm{kg} / \mathrm{d} \text { BID to TID } \\
\text { Enalapril (PO) } 0.08-0.6 \mathrm{mg} / \mathrm{kg} / \mathrm{day} \text { OD-BID } \\
\text { Lisinopril (PO) } 0.1-0.5 \mathrm{mg} / \mathrm{kg} / \mathrm{d} \text { Daily } \\
\text { Quinapril (PO) Initial: } 0.1-0.2 \mathrm{mg} / \mathrm{kg} / \mathrm{d} \text { Daily }\end{array}$ \\
\hline Diuretics & $\begin{array}{l}\text { Amiloride (PO) 0.4-0.625 mg/kg/d Daily to BID } \\
\text { Furosemide (PO) } 1-6 \mathrm{mg} / \mathrm{kg} / \mathrm{dose} \text { Daily to QID } \\
\text { Hydrochlorothiazide (PO) } 1-3 \mathrm{mg} / \mathrm{kg} / \mathrm{d} \text { BID }\end{array}$ \\
\hline Aldosterone antagonist & Spironolactone (PO) 0.5-1.5 mg/kg/dose BID \\
\hline Central- $\alpha$ agonist & Clonidine (PO) 0.05-0.1 mg/dose BID-TID \\
\hline
\end{tabular}

Abbreviations: ACE: Angiotensin-Converting Enzyme; BID: Twice Daily; IV: Intravenous; Max: Maximum; PO: Oral; QID: 4 Times Daily; TID: 3 Times Daily Adopted from [3]

Table 4: Various drugs used in the management of neonatal hypertension.

$95^{\text {th }}$ and $99^{\text {th }}$ percentile) and mild depending upon the value of BP and end-organ dysfunction and treatment will depend upon the severity of presentation (Figure 6) $[3,5,17,22,23]$.

\section{When is the surgical Intervention needed for neonatal HT?}

The indications for surgical treatment of NHT are few and includes renal malformations (renal vessels thrombosis/stenosis, polycystic kidney and renal tumors) and cardiovascular malformations like coarctation of aorta [26-31].

\section{How is the prognosis of neonate with HT?}

The prognosis of NHT depends upon the cause of HT i.e. if cause of iatrogenic than the NHT get resolved once the precipitating factor is removed. If the neonate have features of end organ dysfunction than outcome is not favourable [28]. If the cause of NHT is renal, then HT persists in childhood. Blood pressure usually gets normalized in follow up of neonate who had NHT secondary to bronchopulmonary dysplasia [32].

\section{Conclusion}

Neonatal HT has no clear definition with no proper treatment guidelines. Blood pressure should be measured in described standard manner, with the health care personal taking BP measurement should have sound knowledge of the method. The etiology of neonatal HT should be sought and before starting anti-hypertensive medication, treatable causes of neonatal HT should be sought. The commonest etiology for neonatal hypertension is reno vascular disease. The diagnostic approach includes detailed history taking (prenatal, perinatal and postnatal), clinical examination and laboratory investigations. ACE inhibitors are first line of drugs and should be used after ruling out renal artery stenosis.

\section{References}

1. Sharma D, Farahbakhsh N, Shastri S, Sharma $P(2016)$ Neonatal hypertension J Matern-Fetal Neonatal Med 5: 1-11.

2. Adelman RD (1978) Neonatal hypertension. Pediatr Clin 25: 99-110.

3. Sharma D, Pandita A, Shastri S (2014) Neonatal hypertension: An underdiagnosed condition, a review article. Curr Hypertens Rev 10: 205-212.

4. Pillai A, Sharma D, Kadam $P$ (2016) Hypertension in the neonatal period: An Update. Curr Hypertens Rev 12: 186-195.

5. Dionne JM, Abitbol CL, Flynn JT (2012) Hypertension in infancy: Diagnosis, management and outcome. Pediatr Nephrol Berl Ger 27: 17-32.

6. Blowey DL, Duda PJ, Stokes P, Hall M (2011) Incidence and treatment of hypertension in the neonatal intensive care unit. J Am Soc Hypertens 5: 478483.

7. Samuels J, Bell C, Samuel J, Swinford R (2015) Management of hypertension in children and adolescents. Curr Cardiol Rep 17: 107.

8. Kent AL, Kecskes Z, Shadbolt B, Falk MC (2007) Normative blood pressure data in the early neonatal period. Pediatr Nephrol Berl Ger 22: 1335-1341.

9. Flynn JT (2000) Neonatal hypertension: Diagnosis and management. Pediatr Nephrol Berl 14: 332-341.

10. Davis LL (2015) Hypertension guidelines: Evidence-based treatments for maintaining blood pressure control. Nurse Pract 40: 32-37.

11. Pejovic B, Peco-Antic A, Marinkovic-Eric J (2007) Blood pressure in non-critically ill preterm and full-term neonates. Pediatr Nephrol Berl Ger 22: 249-257.

12. Kent AL, Shadbolt B, Hu E, Meskell S, Falk MC, et al. (2009) Do maternalor pregnancy-associated disease states affect blood pressure in the early neonatal period? Aust N Z J Obstet Gynaecol 49: 364-370.

13. Sedaghat N, Ellwood D, Shadbolt B, Kecskes Z, Falk MC, et al. (2008) The effect of mode of delivery and anaesthesia on neonatal blood pressure. Aust $N$ Z J Obstet Gynaecol 48: 172-178.

14. Seliem WA, Falk MC, Shadbolt B, Kent AL (2007) Antenatal and postnatal risk factors for neonatal hypertension and infant follow-up. Pediatr Nephrol Berl Ger 22: 2081-2087. 
15. Zubrow AB, Hulman S, Kushner H, Falkner B (1995) Determinants of blood pressure in infants admitted to neonatal intensive care units: A prospective multicenter study. Philadelphia Neonatal Blood Pressure Study Group. J Perinatol Off J Calif Perinat Assoc 15: 470-479.

16. Samanta M, Mondal R, Ray S, Sabui T, Hazra A, et al. (2015) Normative blood pressure data for Indian neonates. Indian Pediatr 52: 669-673.

17. Flynn JT (2012) Hypertension in the neonatal period. Curr Opin Pediatr 24: 197-204.

18. Angermeier KW, Kay R, Levin H (1992) Hypertension as a complication of multicystic dysplastic kidney. Urology 39: 55-58.

19. Guay-Woodford LM, Desmond RA (2003) Autosomal recessive polycystic kidney disease: The clinical experience in North America. Pediatrics 111: 1072-1080.

20. MacDermot KD, Saggar-Malik AK, Economides DL, Jeffery S (1998) Prenatal diagnosis of autosomal dominant polycystic kidney disease (PKD1) presenting in utero and prognosis for very early onset disease. J Med Genet 35: 13-16.

21. Fick GM, Johnson AM, Strain JD, Kimberling WJ, Kumar S, et al. (1993) Characteristics of very early onset autosomal dominant polycystic kidney disease. J Am Soc Nephrol 3: 1863-1870.

22. Weinblatt ME, Heisel MA, Siegel SE (1983) Hypertension in children with neurogenic tumors. Pediatrics 71: 947-51.

23. Malone PS, Duffy PG, Ransley PG, Risdon RA, Cook T, et al. (1989) Congenital mesoblastic nephroma, renin production and hypertension. J Pediatr Surg 24 599-600.
24. Abman SH, Warady BA, Lum GM, Koops BL (1984) Systemic hypertension in infants with bronchopulmonary dysplasia. J Pediatr 104: 928-931.

25. Alagappan A, Malloy MH (1998) Systemic hypertension in very low-birth weight infants with bronchopulmonary dysplasia: incidence and risk factors. Am J Perinatol 15: 3-8.

26. Abman SH (2002) Monitoring cardiovascular function in infants with chronic lung disease of prematurity. Arch Dis Child Fetal Neonatal Ed 87: F15-18.

27. Anderson AH, Warady BA, Daily DK, Johnson JA, Thomas MK (1993) Systemic hypertension in infants with severe bronchopulmonary dysplasia: Associated clinical factors. Am J Perinatol 10: 190-193.

28. Torok RD, Campbell MJ, Fleming GA, Hill KD (2015) Coarctation of the aorta: Management from infancy to adulthood. World J Cardiol 7: 765-775.

29. Murki S, Deshbhatla SK, Sharma D, Rao N, Verma S (2014) Congenital ductus arteriosus aneurysm: An unusual cause of transient neonatal hypertension. BMJ Case Rep 2014.

30. Sahu R, Pannu H, Yu R, Shete S, Bricker JT, et al. (2013) Systemic hypertension requiring treatment in the neonatal intensive care unit. J Pediatr 163: 84-88.

31. Shah AB, Hashmi SS, Sahulee R, Pannu H, Gupta-Malhotra M (2015) Characteristics of systemic hypertension in preterm children. J Clin Hypertens Greenwich Conn 17: 364-370.

32. Louw J, Brown S, Thewissen L, Smits A, Eyskens B, et al. (2013) Neonatal circulatory failure due to acute hypertensive crisis: Clinical and echocardiographic clues. Cardiovasc J 24: 72-75. 